\title{
Application of Explanational Translation Approach to English Idioms
}

\author{
Linli Chen \\ School of Cultural Tourism and International Exchange, Yunnan Open University, Kunming, China
}

\begin{abstract}
Idioms, the crystallization of language, are always rich in cultural connotation and national flavor. Translating idioms is quite a difficult task because only a few English idioms have equivalents in Chinese idioms due to linguistic, especially cultural differences. Explanational translation, literal translation, free translation, compensatory translation, borrowing, integrated approach, are six translation tactics in translating English idioms into Chinese. This paper aims to propose the explanational translation approach, one of important and indispensable tactics to Chinese translation of English idioms based on Eugene A. Nida's view on translation and culture. In order to keep the flavor of the original English idioms as well as to cater for the Chinese readers, each tactics should be reasonably employed in the process of translating. It is worth discussing on the application of explanational translation approach to English idioms so as to better use explanational translation tactic in translation, hoping to cast some enlightenment on further research in this field.
\end{abstract}

Index Terms-idioms, semantic, culture, explanational translation, approach

\section{INTRODUCTION}

McCarthy defines idiom as: "strings of more than one word whose syntactic, lexical and phonological form is to a greater or lesser degree fixed and whose semantic and pragmatic functions are opaque and specialized" (1998, p.130). Thus, we cannot make the meaning of the idioms based on our understanding of the individual words that make up of them, since idioms or set phrases are important products of language and culture of a society.

According to Eugene A. Nida, "In transferring the message from one language to another, it is the content which must be preserved at any cost; the form, except in special cases, such as poetry, is largely secondary, since within each language the rules for relating content to form are highly complex, arbitrary, and variable." (Nida \& Taber, 2004, p.105). In his opinion, "if by coincidence it is possible to convey the same content in the receptor language in a form which closely resembles that of the source, so much the better: we preserve the form when we can, but more often the form has to be transformed precisely in order to preserve the content. An excessive effort to preserve the form inevitably results in a serious loss or distortion of the message." (Nida \& Taber, 2004, p.105-106).

\section{The COMMOnest Problems of CONTENT TRANSFER ARISE IN IDIOMS}

Obviously in any translation there will be a type of "loss" of semantic content, but the process should be so designed as to keep this to a minimum (Nida \& Taber, 2004, p.106).

In Nida's opinion, "idioms are some of the most obvious candidates for semantic adjustment, for the very fact that they are idioms means it is unlike that the same type of distinctive form will have the same meaning in another language. The adjustments are quite understandably of three types: (a) from idioms to nonidioms, (b) from idioms to idioms, and (c) from nonidioms to idioms" (ibid).

Frequently idioms are shifted to nonidioms in the process of transfer. For example, "to gird up the loins of the mind" (Peter, 1966, p.13), or "gird (or gird up) one's loins", meaning "summon strength of will to enter vigorously on an enterprise" (Collins, 1960, p.125), may be transferred as "to get ready in one's thinking." And an idiom such as "heap coals of fire on his head" (Rom., 1964, p.20), meaning "make a person who has injured one feel remorse or shame by kindness, generosity, return of good for evil" (Collins, 1960, p.137), becomes "make him ashamed." (Nida \& Taber, 2004, p. 106).

It is possible to match one idiom by another in certain instances. For instance, "in Shipibo, 'to have a hard heart' (a phrase which if translated literally would mean 'to be brave'), is transferred into an idiomatic equivalent, 'his ears have no holes.' In one African language, the epitome of human wisdom is not 'flesh and blood,' (in the phrase 'flesh and blood have not revealed it unto you'), but 'an old man with a single hair.' In certain cases some translators have felt that it is essential to indicate in the margin the exact form of the Biblical idiom. This is entirely all right, but in most instances it is really not necessary" (Nida \& Taber, 2004, p.106).

Whereas one inevitably loses many idioms in the process of translation, one also stands to gain a number of idioms. For instance, "faith" may be rendered - as in Tzeltal - as "to hang on to God with the heart," and "peace," as in a number of African languages, is "to sit down in the heart," Such idiomatic renderings do much to make the translation 
come alive, for it is by means of such distinctive expressions that the message can speak meaningfully to people in terms of their own lives and behavior ${ }^{1}$ (ibid).

It is always complex to render idioms of one language into another, much more so if the two languages involved are of backgrounds and cultures so unlike each other (Deng, 1989, p.40).

\section{NIDA’s VIEW ON TRANSLATION AND CULTURE}

The study of translation theory has gone through a long journey. Many scholars believe that a qualified translator should be not only bilingual, but also bi-cultural, and only in this way, can he/she produce a good translation. Eugene A. Nida, a most authoritative translation theorist and practitioner, also attaches much importance to cultural effect on translation (Chen, 2007).

Since language is a part of culture, translating from one language into another cannot be done satisfactorily without adequate knowledge of the two cultures involved. In the research of translation, Nida, E.A. has become aware of the great importance of cultural factors in translating. He holds that the cultural factors in translating are more significant than the purely linguistic differences. In his view, the most serious mistakes in translating are usually made not because of verbal inadequacy, but of wrong cultural assumptions (Nida, 2001). It can be illustrated in the idiom translation. Source language (SL) idioms are often found to be lively in the SL culture, but hardly understandable, if translated literally, because target language (TL) readers' cultural background, which differs by varying degrees from that of SL readers, often becomes a misleading factor.

For example: "Their boss pays the highest wages, but he wants his pound of flesh in return and makes them work very hard." In this sentence, the idiom "a pound of flesh", which comes from Shakespeare's comedy The Merchant of Venice, means "to insist cruelly on repayment of what was borrowed"; "full payment, however harsh the terms may be. The allusion is to the bargain made by Shylock with Antonio in The Merchant of Venice." (Collins, 1960, p.179). Literally, it is "gē ròu huán zhài; cán kù zhà qǔ" and its implied meaning is "hé fă ér bú hé lì de yào qiú" or "hé qíng dàn bèi yú qíng lǐ de yào qiú" in Chinese (Luo, 2006, p.35). And if you say that you are "as poor as a church mouse", you are emphasizing that you have very little money, it can be translated into "qióng dé xiàng gè jiào huā zĭ" or "jiā tú sì bi" in Chinese. These idioms only have meanings in terms of the cultures in which they function, the translator cannot understand them adequately without careful consideration of their cultural backgrounds. Therefore, "for truly successful translating, biculturalism is even more important than bilingualism, since words only have meanings in terms of the cultures in which they function." (Nida, 2001, p.82) That is, "Only by being in the countries in which a foreign language is spoken can one acquire the necessary sensitivity to the many special meanings of words and phrases." (ibid).

Cultural differences have brought many difficulties to translation, and only by cultural adjustments and modifications, can we successfully reach the goal of "functional equivalence", or go near to its requirements. That is also the close connection between the two important aspects-functional equivalence and cultural factors in Nida's views on translation.

According to Nida, differences of culture may be a reason for having marginal notes in a translated text. That is to say, it's very difficult for you to find a proper word or sentence to transfer the meaning, so you have to add an annotation. For example, "To meet one's waterloo" means "to have a miserable failure" or "to have a crashing defeat", it comes from a famous battle in 1815 called Napolean's Last Battle, whereby Napolean had a miserable failure which led to his eventual failure. In fact, "waterloo" means nothing to Chinese people, while the place name "waterloo" means a lot in the SL culture because of the historical event. In order to make it understand, marginal notes or annotations in a translated text are needed (Chen, 2007).

Since different people may also have differences in their national psychology, which refers to the character, emotion, value and religious belief of a nation, formed in its long process of evolution and development. People are accustomed to their own ways of expressions shaped by their own histories and cultures. Many words have different pragmatic implications in different countries. In a certain context, some words' designative meanings are different from their deep meanings. These differences, seemingly invisible, though are lions in the way for cross-cultural communication and translation. For instance, the term "Judas' kiss", from the Bible, which alludes to the betrayal of Jesus by Judas Iscariot, who kissed him as a way of identifying him to the soldiers who came to arrest him, means "yóu dà zhī wěn, š̌ wáng zhì wěn" with the implication for "chū mài péng yǒu". And people who say "talk turkey" mean "speak seriously and plainly" or "tán zhèng jīng shì, zhi shuài dì jiăng" in Chinese (Chen, 2007).

Different societies may hold different cultural backgrounds. Besides the common features of human society, there also inevitably exist cultural differences. In translation, these cultural differences turn to be cultural obstructions, which are common but never to be simply dealt with since they limit translatability. Cultural factors thus having been one of

\footnotetext{
${ }^{1}$ It is not without interest to note that many persons who readily agree to the addition of idioms, $i$. $e$., changes from nonidioms, are nevertheless reluctant to permit any changes from idioms to nonidioms. But one cannot have his cake and eat it too. What one must give up in order to communicate effectively can, however, be compensated for, at least in part, by the introduction of fitting idioms. One of the difficulties is that too often translators are not sufficiently sensitive to the possibilities of idiomatic expressions, and hence the end result is a weakening of the figurative force of the translation, since they do not compensate for loss of certain idioms by the introduction of others (Nida \& Taber, 2004, p.106).
} 
the greatest reasons to cause translation problem which are 'frequently due to the cultural 'gap' or 'distance' between the source and target languages". (Newmark, 2001, p.94)

It is exactly a hard task to translate English idioms into Chinese due to different cultural backgrounds, but it is of great significance to employ explanational methods of translation in idiom translation based on Nida's view on translation and culture.

\section{USING EXPLANATIONAL APPROACH IN TRANSLATING ENGLISH IDIOMS}

Liberal translation can transfer English cultural information effectively when translating between English and Chinese. However, it is sometimes difficult to find out a suitable Chinese word or expression to employ when translate idioms from English into Chinese. "In many instances idioms can only be satisfactorily rendered by non-idioms in a target language" (Nida, 2001, p.28). Therefore, for the purpose of improving the sending of original meaning of the backgrounds and allusions that are supplied to enhance English idioms, one important and indispensable translating skill may be employed, that is, explanational translation.

Explanational translation approach is quite useful in improving the sending of original meaning of the backgrounds and allusions of English idioms. Take "eats no fish and plays the game" as an example. In the following sentence:

"John can be relied on. He eats no fish and plays the game." can be translated as:

A. John wéi rén kě kào. Tã jì zhōng shí yòu zhèng zhí.

B. John wéi rén kě kào. Tā bù chī yú, bìng qiě cān jiā bì sài.

C. John wéi rén kě kào. Tã jì zhōng shí yòu zhèng zhí. With a note: "eats no fish and

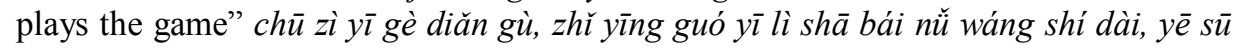
jiào tú wèi le biăo shi duì zhèng fǔ de zhōng chéng, jù jué zūn shǒu făn duì zhèng fŭ de luó mă tiān zhǔ jiào zài xīng qī wǔ zhĭ chī yú de xí sú.

Therefore, "to eat no fish" means "to be loyal", it is "zhōng chéng, guāng míng zhèng dà" in Chinese.

Observing those versions, we find $\mathrm{C}$ is more preferable. Though B expresses the literal meaning of the English idiom "to eat no fish", Chinese people just know the one is clever and witty who likes eating fish. What's more, B has no link with the context. A can let readers know the explanation of "to eat no fish", but not know why. Only C lets readers know the spirit of this idiom as well as the source (Chen, 2007).

By adding the note, readers know that in English history, the conflicts between old Christian religion and Protestantism were vehement. The old religion stipulated that in feast days, people could only eat fish, but Protestants refused to eat fish in feast days to show their decision of converting to Protestantism. So "to eat no fish" means "to be loyal". "To play the game" means "to take part in a match by observing the rules", and it is transferred to mean "being upright and honest". Therefore, this sentence should be translated liberally into C with the supplementary notes.

\section{THE NECESSITY OF EXPLANATORY NOTES}

Liberal translation is by far the most common way of translating idioms when an equivalent cannot be found in the TL or when it seems inappropriate to use idiomatic language in the target text because of differences in stylistic preferences of the source and target languages. You may or may not find the paraphrases accurate (Chen, 2007). This is done at the expense of a neglect of style. In this case, some loss of the rhetorical features, sometimes part of the meaning, is inevitable. The translator attempts to minimize the loss with explanation so as to provide readers with information necessary for appreciating idioms. To those idioms with allusions, readers may be wondering about the stories related to them, though they know the meaning from the paraphrase.

In this case, it is necessary to use concise note to compensate the cultural differences and decrease cultural loss. This method should be cautiously used to avoid tediousness and the explanatory notes are usually footnotes.

For example, "Worth one's salt", which means "being a good worker, or a productive person; worth what one is paid" (He, Wang, \& Chen, 1991, p.483), is liberally translated into "chèn zhî" in Chinese with a footnote "ǧ̌ shí yòng yán fù gōng zī, gù yán zhī.”

"A cat's paw" which means "a person used as a tool by another" is translated into "bèi rén lì yòng de rén" with a note "The allusion is to a fable about a monkey that wished to get some chestnuts from the fire without burning itself, and used the paw of a cat" (Collins, 1960, p.85). It is "yuán yú yù yán, hóu piàn māo huǒ zhōng qǔ lì, māo zhuă tàng shāng, hóu shí li’" in Chinese.

In order to improve the sending of original meaning of the backgrounds and allusions, the translator use an explanatory note to provide the reader with information necessary for appreciating these idioms when there is no equivalent in the TL or when it seems inappropriate to use idiomatic language in the target text. More examples are as follows:

"Damon and Pythias" is translated into "mò nì zhī jiāo" with a note "Damon and Pythias shì gǔ yì dà lì rén, shì mò nì zhī jiāo de diăn fàn". It is said that Damon and Pythias are friends in classical legend so devoted to each other that when Pythias, who had been condemned to death, wanted time to arrange his affairs, Damon pledged his life that his friend would return (Yu \& Guo, 1999, p.26). Its implicated meaning is conveyed completely by its liberal translation "mò nì $z h \bar{\imath}$ jiāo" and the explanatory note. Obviously, it will be better to translate it into "mò nì zhi jiāo" in this way instead of 
"Damon and Pythias", since very few people know the two, if it is rendered literally, readers have to figure out who Damon and Pythias are, what the implicated meaning and the source are, which will make readers puzzled under certain circumstances.

In translating "Pour oil on troubled waters" into "píng $x \bar{l} f e ̄ n g ~ b \overline{o " ~ i n ~ C h i n e s e ~ w i t h ~ t h e ~ f o o t n o t e ~ " c h u a ́ n ~ s h u o ̄ ~ h a ́ n g ~ h a ̆ i ~}$ yù dào fêng làng, ruò bă yóu dào rù hăi lǐ, kě píng xī hăi làng”, the explanational translation is applied so as to make its implicated meaning and spirit clear to readers. It is obvious that "ping $x \bar{\imath}$ fêng $b \bar{o}$ " can convey effectively the meaning of the idiom: "calm a disagreement, violent dispute, etc., or bring about appeasement in a disturbed condition. The allusion is to the fattening effect of oil on waves" (Collins, 1960, p.179) and the explanatory note can make its source known.

In order to compensate the cultural differences and decrease cultural loss, as well as improve the sending of original meaning of the backgrounds and allusions, explanatory notes are used in the above examples so as to provide the reader with information necessary for appreciating these idioms.

\section{CONCLUSION}

According to Nida and Taber (1969), "translating consists in reproducing in the receptor language the closest natural equivalent of the source language message, first in terms of meaning and secondly in terms of style" (p.12) and the success of the translation depends above all on achieving equivalent response. In Nida's view, translating was to reproduce "the closest natural equivalent to the source-language message" in the receptor language, not to get something completely identical (Nida \& Taber, 1969, p.12). Later on, he said emphatically, “"Equivalence' cannot be understood in its mathematical meaning of identity, but only in terms of proximity, i.e. on the basis of degrees of closeness to functional identity" (Nida, 1993, p.117). It is obvious that in Nida's theory, the term "equivalence" is used in a relative sense, i.e. the closest possible approximation to the source-language message. According to Nida's view of culture, cultural awareness should always be kept in mind while translating. Language and culture do not always match from one language to another although they are closely related.

The application of explanational translation approach in translating English idioms into Chinese makes the gap between both cultures and languages narrow and makes cultural exchange among countries more possible. This paper is just a preliminary research on explanational translation approach of English idioms in the perspective of semantic adjustment. It is believed that further research and more explorations in this field are worthy and in great need.

\section{REFERENCES}

[1] Akmajian, A. (1995). An Introduction to Language and Communication. London: The MIT Press.

[2] Budick, Sanford and Wolfgang Iser. (1999). The Translatability of Cultures. California: Stanford University Press.

[3] Burchfield R. W. (ed). (1989). Oxford English Dictionary. Oxford: Clarendon Press.

[4] Chen Linli. (2018). The Application of Dynamic Equivalence in Translation of Ethnic Culture. International Journal of Language and Linguistics, Vol. 5, No 2, 74-77.

[5] Chen Linli. (2010). On Integrated Translation Approach of English Idioms. Journal of Language Teaching and Research, Vol. 1, No 3, 227-230.

[6] Chen Linli. (2009). On Literal Translation of English Idioms. English Language Teaching, Vol.2, No.2, 164-166.

[7] Chen Linli. (2009). On Translatability of English Idioms. Asian Social Science. Vol. 5, No 2, , 43-44.

[8] Chen Linli. (2007). On the Chinese Translation of English Idioms (MA Thesis). Shanghai International Studies University, Shanghai, China.

[9] Chomsky, N. (1965). Aspects of the Theory of Syntax. Cambridge, Mass.: MIT Press.

[10] Collins, V. H. (1960). A Book of English Idioms with Explanations. London, New York and Toronto: Longman, Green and Co.

[11] Coulson. J. (1978). The New Oxford Illustrated Dictionary. Oxford: Oxford University Press.

[12] Cowie, A.P. and R Mackin. (eds). (1975). Oxford Dictionary of Current Idiomatic English, Vol. 1. London: Oxford University Press.

[13] Cowie, A P., R. Mackin, and I. R. McCaig (eds.). (1983). Oxford Dictionary of Current Idiomatic English, Vol. 2. Oxford: Oxford University Press.

[14] Deng Yanchang, Liu Runqing. (1989). Language and Culture. Beijing: Foreign Language Teaching and Research Press.

[15] Fernando, Chitra. (2000). Idioms and Idiomaticity. Shanghai: Shanghai Foreign Language Education Press.

[16] Fowler, H. W. (1985). A Dictionary of Modern English Usage. New York: Oxford University Press.

[17] Gentzler, E. (1993). Contemporary Translation Theories. London and New York: Routledge.

[18] He Xiulan, Wang Longdi, Chen Zheng. (1991). Commonly Used American Idioms. Beijing: Beihang University Press.

[19] Long, T. H. (1979). Longman Dictionary of English Idioms. London: Longman Group Limited.

[20] Luo Shiping. (2006). A Research on English Idioms. Shanghai: Shanghai Foreign Language Education Press.

[21] Ma Huijuan. (2003). A Study on Nida's Translation Theory. Beijing: Foreign Language Teaching and Research Press.

[22] McCarthy, M. (1998). Spoken Language and Applied Linguistics. Cambridge: Cambridge University Press.

[23] McIntosh, A. (1966). 'Patterns and ranges' in McIntosh, A. et al. (eds) Patterns of language: Papers in General, Descriptive and Applied Linguistics, 182-99. London: Longman.

[24] McLay, V. (1987). Idioms at Work. Sussex: Language Teaching Publications.

[25] McMordie, W. (revised by Goffin, R.). (1972). English Idioms. London: Oxford University Press.

[26] Makkai, Adam. (1972). Idiom Structure in English. Paris: The Hague.

[27] Newmark, Peter. (1981). Approaches to Translation. Oxford: Pergmon Press.

[28] Newmark, Peter. (1991). About Translation. Clevedon: Multilingual Matters. 
[29] Newmark, Peter. (1993). Paragraphs on Translation. Clevedon: Multilingual Matters.

[30] Newmark, Peter. (2001). A Textbook of Translation. Shanghai: Shanghai Foreign Language Education Press.

[31] Nida, Eugene. A. (1964). Towards a Science of Translating. Brill. Leiden.

[32] Nida, Eugene. A. (2001). Language, Culture, and Translating. Shanghai: Shanghai Foreign Language Education Press.

[33] Nida, Eugene.A. (2002). Language and Culture: Contexts in Translating. Shanghai: Shanghai Foreign Language Education Press.

[34] Nida, Eugene. A. (1986). From one Language to Another. Shanghai: Shanghai Foreign Language Education Press.

[35] Nida, Eugene.A. \& Charles R. Taber. (2004). The Theory and Practice of Translation. Shanghai: Shanghai Foreign Language Education Press.

[36] Nida, Eugene. A. and C. Taber. (1969). The Theory and Practice of Translation. Leiden: E. J. Brill.

[37] Peaty, D. (1983). Working With English Idioms. Walton-on-Thames: Thomas Nelson and Sons Ltd.

[38] Robinson, D. (1997). What is Translation? Centrifugal Theories, Critical Interventions. Kent: the Kent State University Press.

[39] Sapir, E. (1956). Culture, Language and Personality. Los Angeles: University of California Press.

[40] Smith, L P. (1925). Words and Idioms. London: Constable.

[41] Snell-Hornby, M. (1988). Translation Studies: An Integrated Approach. Amsterdam: John Benjamins.

[42] Venuti, L. (1995). The Translator's Invisibility -- A History of Translation. London and New York: Routledge.

[43] Webster, N. (2006). Webster's Dictionary of the English Language. (Unabridged). New York: Webster's New World.

[44] Whorf, B. L. (1956). Language, Thought, and Reality: Selected Writings of Benjamin Lee Whorf. ED. John B. Carroll. Cambridge, MA: MIT Press.

[45] Wilss, W. (1982). The Science of Translation: Problems and Methods. Gunter Narr verlag: Tübingen.

[46] Wood, F. T. (1966). English Verbal Idioms. London: Macmillan.

[47] Wood, F. T. (1969a). English Prepositional Idioms. London: Macmillan.

[48] Wood, F. T. (1969b). English Colloquial Idioms. London: Macmillan.

[49] Xiao Junshi. (1982). An Approach to Translation From Chinese into English And Vice Versa. Beijing: The Commercial Press.

[50] Yu Fumin, Guo Shanlian. (1999). A Comparative Study of English and Chinese Idioms. Shanghai: Shanghai Jiao Tong University Press.

Linli Chen, PhD, a visiting Scholar of the Ohio State University, she is currently working as an Associate Professor at Yunnan Open University, Kunming, Yunnan, China. Her research interests mainly include English language and culture, translation theories, cross-cultural studies and ethnic culture. 